\title{
The effect of intake on protein metabolism across splanchnic tissues in growing beef steers
}

\author{
H. Lapierre ${ }^{1}$, J. F. Bernier ${ }^{2}$, P. Dubreuil ${ }^{3}$, C. K. Reynolds ${ }^{4}$, C. Farmer $^{1}$, D. R. Ouellet ${ }^{1}$ and G. E. Lobley ${ }^{5}$ \\ ${ }^{1}$ Dairy and Swine Research and Development Centre, Agriculture and Agri-Food Canada, Lennoxville, \\ Quebec, Canada J1M 1 Z3 \\ ${ }^{2}$ Département des sciences animales, Université Laval, Ste-Foy, Québec, Canada G1K 7P4 \\ ${ }^{3}$ Faculté de médecine vétérinaire, Université de Montréal, St-Hyacinthe, Québec, Canada J2S 7C6 \\ ${ }^{4}$ Cedar, University of Reading, Reading RG6 6AT, UK \\ ${ }^{5}$ Rowett Research Institute, Bucksburn, Aberdeen AB21 9SB, UK
}

(Received 29 September 1998 - Revised 16 December 1998 - Accepted 4 February 1999)

\begin{abstract}
The contribution of the total splanchnic tissue (TSP; portal-drained viscera (PDV) plus liver) to whole-body protein metabolism was estimated in relation to intake $(0.6,1.0$ and $1.6 \times$ maintenance requirements), in six multicatheterized growing beef steers used in a double $3 \times 3$ Latin square design. At the end of each $21 \mathrm{~d}$ experimental period, $\left[1-{ }^{13} \mathrm{C}\right]$ leucine was infused into a jugular vein $(1.05 \mathrm{mmol} / \mathrm{h}$ for $5 \mathrm{~h}$, preceded by a priming dose of $1.05 \mathrm{mmol})$. Arterial, portal and hepatic blood samples were collected hourly during the infusion. The increment in TSP leucine irreversible loss rate (ILR) observed with increasing intake reached significance $(P<$ $0 \cdot 10)$ only for PDV, while whole-body ILR increased markedly $(P<0 \cdot 001)$ with intake. The relative contribution of TSP to whole-body leucine ILR averaged $44 \%$ (25\% from PDV and $19 \%$ from the liver). Although these proportions were not affected by intake, on an incremental basis more than $70 \%$ of the increase of whole-body leucine ILR between the 0.6 and $1.0 \times$ maintenance originated from the changes in TSP ILR, while the corresponding value was below $13 \%$ between 1.0 and $1.6 \times$ maintenance. Total whole-body leucine oxidation and fractional oxidation increased $(P<0.05)$ with intake. Protein retention increased with intake $(P<0.01)$, as a result of a greater increase in protein synthesis compared with protein degradation. Protein breakdown had a major impact on protein turnover as $65 \%$ of the protein synthesized was degraded when intake varied from 1.0 to $1.6 \times$ maintenance. Net leucine portal absorption increased $(P<0.001)$ with intake and represented 1,16 and $23 \%$ of whole body leucine ILR, for $0.6,1.0$ and $1.6 \times$ maintenance, respectively. Although leucine oxidation was not a major component of whole body ILR (9.3-19.9\%), it represented $69 \%$ of the net available leucine (portal absorption) even at $1.6 \times$ maintenance. The lower relative contribution of the TSP to whole-body leucine ILR at higher intake indicates the proportional increase in the metabolic activity of peripheral tissues as the animals moved into positive protein balance.
\end{abstract}

Protein: Metabolism: Splanchnic tissues

The metabolic fate of amino acids is determined by biochemical reactions occurring during absorption across the digestive tract, partition between anabolic and catabolic transformations in the liver, and finally, involvement in the processes of protein synthesis and degradation coupled, where appropriate, with oxidative mechanisms in the productive peripheral organs. The absolute and relative contributions of each of these components determine the metabolic efficiency with which diet-derived amino acids are used and, thus, the overall productive status of the animal.
In cattle, a number of studies have used the isotope dilution technique to investigate responses of whole-body protein turnover to either nutritional (e.g. Hammond et al. 1987; Lobley et al. 1987) or hormonal (e.g. Lobley et al. 1985; Eisemann et al. 1986) interventions. Only limited information is available, however, on protein turnover of the splanchnic tissue. Available data for visceral organ metabolism have involved somatotropin treatment (Eisemann et al. 1989a; Early et al. 1990) or nutritional changes combined with cold environment (Scott et al. 1993). In

\footnotetext{
Abbreviations: GIT, gastrointestinal tract; IE, isotopic enrichment; ILR, irreversible loss rate; MOP, 4-methyl 2-oxopentanoate; PDV, portal-drained viscera; TSP, total splanchnic tissue.

* Corresponding author: Dr Hélène Lapierre, fax +1 819564 5507, email lapierreh@em.agr.ca
} 
these experiments, terminal procedures were used and interanimal variability may have obscured treatment responses. An alternative approach which allows repeated trans-organ measurements, involves veno-arterial techniques coupled with the infusion of an isotopic tracer. Such studies have been successfully applied to other bovine tissues such as the hindlimb (Boisclair et al. 1993) and the mammary gland (Bequette et al. 1996), and the splanchnic tissues of other ruminants (e.g. Lobley et al. 1992, 1996).

The current study extended such approaches to growing steers and monitored the net and the isotopic transfer of leucine across both the digestive tract and the liver as intake was varied from below to above maintenance. Because splanchnic tissues are considered to contribute between 30 and $50 \%$ of protein turnover in cattle (Lobley et al. 1980; Early et al. 1990), they will exert a major influence on both net and gross movements of amino acids within the animal.

\section{Materials and methods}

\section{Animals and treatments}

Six growing beef steers, averaging 398 (SD 27) kg, were used in a double Latin-square design balanced for residual effects (Gill, 1978). The diet (24.4 g N: $245 \mathrm{~g}$ lucerne (Medicago sativa) meal, $640 \mathrm{~g}$ ground maize, $110 \mathrm{~g}$ soyabean meal and $5 \mathrm{~g}$ vitamin and mineral premix, all per $\mathrm{kg}$ as fed) was offered at three intakes: 27 (low), 45 (medium) and 72 (high) $\mathrm{g} / \mathrm{kg}$ body weight ${ }^{0.75}$. The low, medium and high intake levels averaged 62 and $67 \%, 104$ and $111 \%, 166$ and $177 \%$ of estimated energy and protein requirements for maintenance respectively (National Research Council, 1984). Two steers from the high intake treatment did not eat all their feed allowance and, in order to avoid refusals, were offered only $63 \mathrm{~g} / \mathrm{kg}$ body weight ${ }^{0.75}$. The diet was offered in twelve equal meals daily by means of automated feeders. Each experimental period lasted for 3 weeks.

At least 6 months before the beginning of the experiment, the steers were surgically implanted with two catheters in distal mesenteric veins and one each into the portal and the hepatic veins plus the caudal aorta, the latter reached via a mesenteric artery (Huntington et al. 1989). The right carotid artery was surgically elevated to a subcutaneous position, to provide an alternative source of arterial blood should the aortal catheter fail. This occurred for two animals. The experimental protocol was approved by the Institutional Committee for Animal Care of the Lennoxville Research Centre and animals were cared for according to guidelines of the Canadian Council on Animal Care (1993).

\section{Infusions and sampling}

On day 20 of each experimental period, a solution of $\left[{ }^{13} \mathrm{C}\right]$ sodium bicarbonate (99 atom \%; MSD Isotopes, Montreal, Quebec, Canada; $100 \mathrm{mM}$ in sterile $0.15 \mathrm{M}-\mathrm{NaCl}$ ) was infused via a jugular catheter, inserted the previous day, at a rate of $0.165 \mathrm{mmol} / \mathrm{h}$ for $5 \mathrm{~h}$ (from 09.00 to 14.00 hours) preceded by a priming dose of $0.24 \mathrm{mmol}$ (equivalent to 1.4 times the hourly rate; Wolfe, 1984). Breath samples were collected through a face mask (Chevalier et al. 1984): three samples were collected during the hour preceding the beginning of the infusion to determine ${ }^{13} \mathrm{C}$ natural abundance in $\mathrm{CO}_{2}$ and then at $1 \cdot 5,2,3,4$ and $5 \mathrm{~h}$ after the beginning of the infusion. The $\mathrm{CO}_{2}$ was purified from breath samples on a vacuum line, using differential freezing with a solid $\mathrm{CO}_{2}-$ acetone mixture and liquid $\mathrm{N}_{2}$ (Chevalier et al. 1984).

On day 21, a solution of $\left[1-{ }^{13} \mathrm{C}\right]$ leucine (99 atom \%; MSD Isotopes; $67 \mathrm{mM}$ in sterile $0 \cdot 15 \mathrm{M}-\mathrm{NaCl}$ ) was infused into a jugular vein at a rate of $1.05 \mathrm{mmol} / \mathrm{h}$ for $5 \mathrm{~h}$ (from 09.00 to 14.00 hours) preceded by a priming dose of $1.05 \mathrm{mmol}$ (equivalent to the hourly rate; Wolfe, 1984). Blood was simultaneously withdrawn from the arterial, portal and hepatic catheters into heparinized syringes. Blood samples were collected twice in the hour preceding the infusion, to determine $\left[{ }^{13} \mathrm{C}\right]$ leucine natural abundance, and then at 1.5 , 2, 3, 4 and $5 \mathrm{~h}$ after the onset of the infusion. Plasma flows for the portal-drained viscera (PDV) and the liver were determined by downstream dilution of sodium $p$-aminohippurate $(100 \mathrm{~g} / \mathrm{l})$ infused continuously $(6.6 \mathrm{~g} / \mathrm{h})$ over the same period as leucine, into one mesenteric vein catheter, following a priming dose of $2 \mathrm{~g}$.

Immediately after collection, two $1 \mathrm{ml}$ portions of blood were injected into evacuated vacutainers containing $1 \mathrm{ml}$ frozen lactic acid for measurement of $\mathrm{CO}_{2}$ enrichment ( Read et al. 1984). The remainder of the blood was kept on ice and centrifuged, as soon as possible, at $3000 \mathrm{~g}$ for $15 \mathrm{~min}$. The harvested plasma was stored at $-20^{\circ}$ until analysed. During the leucine infusion, breath samples were collected and processed similarly as in the bicarbonate infusion.

\section{Laboratory analyses}

The concentration of $p$-aminohippurate was determined with an automatic analyser (Technicon Autoanalyser II, Technicon Instruments Corporation, Tarrytown, NY, USA), as described previously (Reynolds et al. 1992). Previous trials had shown (JP Blouin and H Lapierre, unpublished results) that negligible quantities of $\mathrm{N}$-acetyl $p$-aminohippurate are produced by the liver of cattle relative to blood flow rate and therefore the de-acetylation involving heating at $100^{\circ}$ for $1 \mathrm{~h}$ before analysis was unnecessary, which contrasts with the situation in sheep (Katz \& Bergman, 1969).

After deproteinization of $1 \mathrm{ml}$ plasma with $25 \mathrm{mg}$ sulfosalicylic acid, leucine concentration was determined by ion-exchange chromatography, with ninhydrin as the colorimetric reagent (LKB 4400 Amino Acid Analyser; LKB Biochrom Ltd, Cambridge, Cambs., UK). Isotopic enrichments (IE) of plasma free leucine and the oxo-acid, 4-methyl 2-oxopentanoate (MOP), were determined after deproteinization with sulfosalicylic acid and derivatization with N-(tert-butyldimethylsilyl)-N-methyltrifluoroacetamide-acetronile $(1: 1, \mathrm{v} / \mathrm{v})$, for $\mathrm{m} / \mathrm{z}$ ions 302,303 for leucine and 259, 260 for MOP, by GC-mass spectrometry (Trio-1; VG Masslab, Manchester, UK), as described by Calder \& Smith (1988).

Purified breath $\mathrm{CO}_{2}$ was analysed for ${ }^{13} \mathrm{C}$ IE as $\mathrm{m} / \mathrm{z}$ ions $44,45,46$ on a triple collector isotopic ratio mass spectrometer (Sira 12; VG Masslab). The blood samples taken for the determination of blood ${ }^{13} \mathrm{CO}_{2} \mathrm{IE}$, to quantify trans-tissue leucine oxidation, were transported to the laboratory of 
analysis stored in solid $\mathrm{CO}_{2}$. Unfortunately, under the $-70^{\circ}$ conditions, the vacutainer seals leaked and the samples became contaminated. The transorgan oxidation data were thus greatly restricted and are not included in the present paper. Further studies showed that samples could have been reacted and then transported at room temperature without detriment for up to 3 weeks (E Milne, personal communication). IE for leucine, $\mathrm{MOP}$ and $\mathrm{CO}_{2}$ were corrected for background abundance and expressed as atom percent excess.

\section{Calculations}

Plasma flows across the PDV and the liver were calculated from downstream dilution of $p$-aminohippurate according to Katz \& Bergman (1969). Net fluxes of leucine were obtained by multiplying the venous-arterial concentration differences by plasma flow.

For all given equations, the rate of infusion is $\mathrm{mmol} / \mathrm{h}$ and the IE of the infusate, leucine, MOP or $\mathrm{CO}_{2}$ is atom percent excess. Whole-body leucine irreversible loss rate (ILR, $\mathrm{mmol} / \mathrm{h}$ ) was calculated as follows:

$$
\begin{aligned}
\text { whole-body ILR }= & \text { (rate of leucine infusion } \\
& \times \text { IE of infusate }) / \mathrm{IE}_{\mathrm{pp}},
\end{aligned}
$$

where $\mathrm{IE}_{\mathrm{pp}}$ represents the isotopic enrichment of the chosen precursor pool (plasma arterial free leucine or MOP). The IE of plasma free leucine or MOP was calculated as the arithmetic mean of samples taken between 1.5 and $5 \mathrm{~h}$ of infusion.

The whole-body fractional rate of leucine oxidation (FO) was calculated using the following equation:

$$
\begin{aligned}
\mathrm{FO}= & \mathrm{IE} \text { of expired } \mathrm{CO}_{2} \times \mathrm{CO}_{2} \text { production }(\mathrm{mmol} / \mathrm{h}) / \\
& (\text { rate of leucine infusion } \times \mathrm{IE} \text { of infusate } \times \mathrm{c}),
\end{aligned}
$$

the IE of $\mathrm{CO}_{2}$ being measured on the day of leucine infusion. The $\mathrm{CO}_{2}$ production was estimated by bicarbonate infusion and calculated as:

$$
\begin{aligned}
\mathrm{CO}_{2} \text { production }= & ((\text { rate of bicarbonate infusion } \\
& \left.\times \text { IE of infusate/IE of expired } \mathrm{CO}_{2}\right) \\
& - \text { rate of infusion }) \times \mathrm{c},
\end{aligned}
$$

where the IE of $\mathrm{CO}_{2}$ was measured on the day of bicarbonate infusion. The coefficient $\mathrm{c}$ is a correction factor for labelled $\mathrm{CO}_{2}$ sequestered in the animal and not expired. It was not estimated in the present study as it is present as a numerator and denominator in the calculation of fractional oxidation and, therefore, self-cancels.

All the following estimations of leucine and protein kinetics were calculated, when needed, with ILR estimated using plasma arterial MOP as the precursor pool. Wholebody leucine oxidation $(\mathrm{LO}, \mathrm{mmol} / \mathrm{h})$ was calculated as follows:

$$
\mathrm{LO}=\mathrm{ILR} \times \mathrm{FO} .
$$

Leucine used for whole-body protein synthesis was calculated as the difference between whole-body ILR and leucine oxidation. Protein synthesis was then estimated assuming a constant fraction of $60 \mathrm{~g}$ leucine $/ \mathrm{kg}$ synthesized protein
(Lobley et al. 1980). The following estimations were calculated using a simple two-compartment model, assuming that:

$$
\begin{aligned}
\text { leucine whole-body ILR = } & \text { leucine used for protein } \\
& \text { plus leucine oxidation } \\
= & \text { leucine portal absorption } \\
& \text { plus leucine from protein } \\
& \text { degradation. }
\end{aligned}
$$

Thus, leucine retained as protein (which equals leucine used for protein synthesis minus leucine from protein degradation) was obtained from net portal absorption of leucine minus leucine oxidation. Based on results obtained in cattle (Lapierre et al. 1997), PDV leucine oxidation, estimated as $27.5 \%$ of whole-body leucine oxidation, was removed from whole-body leucine oxidation as this catabolism had already contributed to net portal absorption. Leucine released from protein degradation was calculated, therefore, as leucine used for protein synthesis minus leucine retained as protein. Leucine released from protein degradation and retained as protein were scaled to protein using the factor, $60 \mathrm{~g}$ leucine/ $\mathrm{kg}$ protein.

Leucine total fluxes (ILR; mmol/h) through the PDV, the liver and the total splanchnic tissue (TSP) were calculated as follows:

$$
\begin{aligned}
\text { PDV ILR }= & \left(\mathrm{IE}_{\text {leu-P }} \times\left[\mathrm{leu}_{\mathrm{p}}\right]-\mathrm{IE}_{\text {leu-A }} \times\left[\mathrm{leu}_{\mathrm{A}}\right]\right) \\
& \times \mathrm{PF}_{\mathrm{P}} / \mathrm{IE}_{\mathrm{pp}}, \\
\text { liver ILR }= & \left(\left(\left(\mathrm{IE}_{\text {leu-H }} \times\left[\mathrm{leu}_{\mathrm{H}}\right]-\mathrm{IE}_{\text {leu-P }} \times\left[\mathrm{leu}_{\mathrm{P}}\right]\right) \times \mathrm{PF}_{\mathrm{P}}\right)\right. \\
& +\left(\left(\mathrm{IE}_{\text {leu-H }} \times\left[\mathrm{leu}_{\mathrm{H}}\right]\right.\right. \\
& \left.\left.\left.-\mathrm{IE}_{\text {leu-A }} \times\left[\mathrm{leu}_{\mathrm{A}}\right]\right) \times \mathrm{PF}_{\mathrm{A}}\right)\right) / \mathrm{IE}_{\mathrm{pp}}, \\
\text { TSP ILR }= & \left(\mathrm{IE}_{\text {leu-H }} \times\left[\mathrm{leu}_{\mathrm{H}}\right]-\mathrm{IE}_{\text {leu-A }}\right. \\
& \left.\times\left[\mathrm{leu}_{\mathrm{A}}\right]\right) \times \mathrm{PF}_{\mathrm{H}} / \mathrm{IE}_{\mathrm{pp}},
\end{aligned}
$$

where $\mathrm{IE}_{\text {leu }}$ and [leu] represent, respectively, the IE and concentration of plasma free leucine. Each subscript indicates the site of plasma collection (A for artery, $\mathrm{P}$ for portal vein and $\mathrm{H}$ for hepatic vein) and $\mathrm{PF}$ represents the plasma flow in the corresponding blood vessels. The subscript 'pp' indicates that calculations were obtained using, as representative of the IE of the precursor pool, the IE of either free plasma leucine or MOP from different sites (venous or arterial).

For both net and total fluxes, a negative veno-arterial difference indicates tissue uptake whereas a positive value denotes a release.

\section{Statistical analyses}

Means obtained for each steer on each sampling day for each experimental period were treated by an ANOVA according to the double Latin-square design using the general linear models procedure of SAS (1985; Statistical Analysis Systems Institute Inc., Cary, NC, USA). Treatment means were separated using orthogonal contrasts, testing for the linear and the quadratic effects of intake (Gill, 1978). A linear effect indicates that between the low and the high intake, there is a significant difference; a quadratic effect 
Table 1. Whole-body leucine kinetics $(\mathrm{mmol} / \mathrm{h}$ ) in growing beef steers fed at different intake levels* (Values are least squares means with the maximal standard error of the mean)

\begin{tabular}{|c|c|c|c|c|c|c|}
\hline \multirow{2}{*}{ Intake... } & \multirow{2}{*}{$\begin{array}{l}\text { Low } \\
(n 6)\end{array}$} & \multirow{2}{*}{$\begin{array}{l}\text { Medium } \\
\quad(n 5)\end{array}$} & \multirow{2}{*}{$\begin{array}{l}\text { High } \\
(n 6)\end{array}$} & \multirow[b]{2}{*}{ SEM } & \multicolumn{2}{|c|}{$\begin{array}{l}P \text { value for } \\
\text { treatment effect }\end{array}$} \\
\hline & & & & & linear & $\overline{\text { quadratic }}$ \\
\hline WB ILR ${ }_{\text {MOP-a }} \dagger$ & 37.9 & 43.8 & $57 \cdot 3$ & 0.76 & 0.001 & 0.07 \\
\hline WB ILR ${ }_{\text {leu-a }} \ddagger$ & $27 \cdot 4$ & 31.7 & 44.6 & 0.84 & 0.001 & 0.04 \\
\hline Oxidation§ & 3.6 & $7 \cdot 6$ & 11.6 & 1.28 & 0.002 & 0.58 \\
\hline $\mathrm{FO}(\%)$ & 9.3 & $17 \cdot 3$ & $19 \cdot 9$ & 2.57 & 0.02 & 0.26 \\
\hline Protein synthesis§ & 34.4 & $36 \cdot 2$ & $45 \cdot 8$ & 1.44 & 0.001 & $0 \cdot 15$ \\
\hline
\end{tabular}

WB ILR, whole-body irreversible loss rate; FO, fractional oxidation rate.

* For details of diets and procedures, see pp. 458-460.

† Calculated using plasma arterial 4-methyl 2-oxopentanoate (MOP-a) for the precursor pool.

$\ddagger$ Calculated using plasma arterial leucine (leu-a) for the precursor pool.

$\S$ Calculated from WB ILR MOP-a.

would indicate that the value obtained for the medium intake level is not intermediate between the low and the high intakes. Both effects may be significant for the same parameter; when this happens they cannot be considered independently. Results obtained for ILR using different precursor pools were compared using the repeated statement of the general linear models procedure of SAS, using the same factors for the main effects and testing the selected precursor pool as the repeated effect. The interaction between treatment and the precursor pool was tested using the orthogonal contrasts (Gill, 1978).

\section{Results}

As the experiment was started several months after surgery, four steers had the three catheters patent for blood sampling, one animal did not have a functional hepatic vein catheter, while a last steer had only the arterial catheter patent. This latter steer also died from an acute enteritis, not related to the experimental treatments, before the completion of the last treatment, at medium intake. Therefore, results are for $n 6$ (except for the medium treatment where $n 5$ ) for wholebody metabolism, $n 5$ for PDV data and $n 4$ for liver and TSP values. Three experimental periods could not be conducted as scheduled but were completed at the end of the planned schedule.

\section{Whole-body metabolism}

Whole-body leucine kinetics are presented in Table 1. Leucine whole-body ILR increased $(P<0.01)$ with intake, regardless of whether the IE of arterial leucine or MOP was chosen as representative of the precursor pool. The quadratic effect $(P=0.04)$ observed with leucine as the precursor pool or the tendency $(P=0.07)$ with MOP as the precursor pool, indicates however, that the difference was larger between medium and high compared with low to medium. On average, mean values obtained using MOP were $34 \%$ greater $(P<0.01)$ than those based on leucine, but there was no significant interaction $(P>0 \cdot 20)$ between treatments and the selected precursor pool, when this latter was included as the repeated effect in the ANOVA. This indicates that although different numerical values were obtained with the different precursor pools, there was no bias introduced by the choice of precursor pool. Leucine oxidation increased linearly $(P<0.01)$ with intake, as did fractional oxidation $(P=0 \cdot 02)$. The $\mathrm{CO}_{2}$ production, uncorrected for $\mathrm{CO}_{2}$ sequestration, increased linearly $(P<0.001)$ with intake (Table 2). Leucine used for protein synthesis increased linearly $(P<0 \cdot 001)$.

Protein kinetics are presented for the five steers with patent portal vein catheters allowing estimation of protein degradation and retention (Table 3). Protein synthesized per

Table 2. Nitrogen intake, carbon dioxide production and splanchnic plasma flows in growing beef steers fed at different intake levels*

(Values are least squares means with the maximal standard error of the mean)

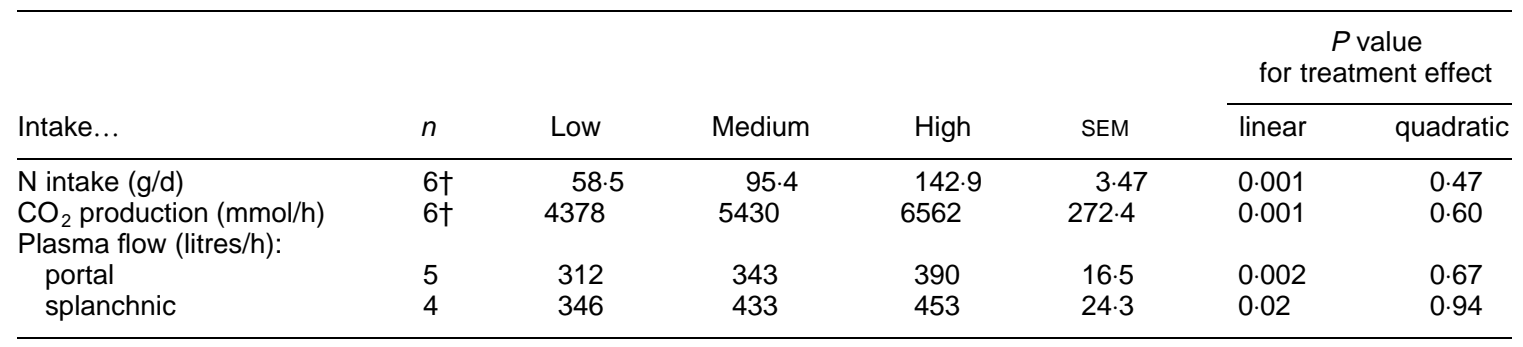

${ }^{*}$ For details of diets and procedures, see pp. 458-460.

† Except for medium intake where $n 5$. 
Table 3. Whole-body protein kinetics $(\mathrm{g} / \mathrm{d})$ in growing beef steers fed at different intake levels* (Values are least squares means with their standard errors, for five steers)

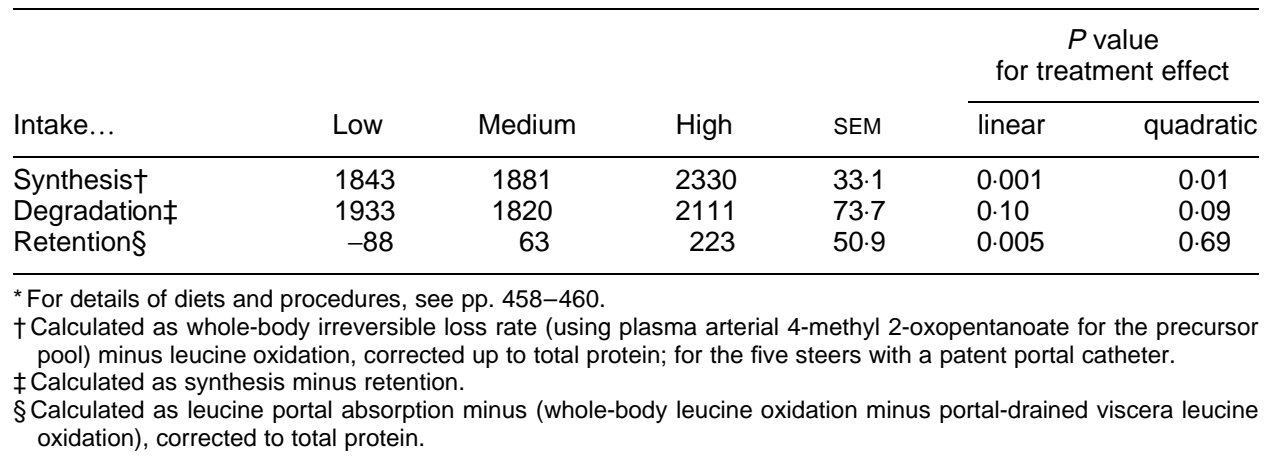

Table 4. Leucine net flux ( $\mathrm{mmol} / \mathrm{h}$ ) across the splanchnic tissue (TSP) of growing beef steers fed at different intake levels*

(Values are least squares means with their standard errors for five (PDV) or four (liver and TSP) steers)

\begin{tabular}{llccccc}
\hline & & & & \multicolumn{2}{c}{$\begin{array}{c}P \text { value } \\
\text { for treatment effect }\end{array}$} \\
\cline { 4 - 6 } Intake... & Low & Medium & High & SEM & linear & quadratic \\
\hline Tissue & & & & & & 0.49 \\
PDV & 0.42 & 6.86 & 13.36 & 1.378 & 0.001 & 0.42 \\
Liver & -0.63 & -0.12 & -1.59 & 0.859 & 0.44 & 0.63 \\
TSP & -0.20 & 5.13 & 11.78 & 0.877 & 0.001 & \\
\hline
\end{tabular}

PDV, portal-drained viscera.

${ }^{*}$ For details of diets and procedures, see pp. 458-460.

Table 5. Leucine kinetics (mmol/h) through the splanchnic tissue (TSP) of growing beef steers fed at different intake levels*

(Values are least squares means with their standard errors for five (PDV) or four (liver and TSP) steers)

\begin{tabular}{|c|c|c|c|c|c|c|c|}
\hline \multirow[b]{2}{*}{ Tissue } & \multirow[b]{2}{*}{ Intake... } & \multirow[b]{2}{*}{ Low } & \multirow[b]{2}{*}{ Medium } & \multirow[b]{2}{*}{ High } & \multirow[b]{2}{*}{ SEM } & \multicolumn{2}{|c|}{$\begin{array}{c}P \text { value } \\
\text { for treatment effect }\end{array}$} \\
\hline & & & & & & linear & quadratic \\
\hline \multirow[t]{4}{*}{ PDV } & $\mathrm{ILR}_{\text {leu-a }} \dagger$ & $-7 \cdot 6$ & -7.9 & -10.5 & 1.02 & 0.08 & 0.53 \\
\hline & ILR $_{\text {leu-p }}$ & -9.8 & -10.9 & $-15 \cdot 2$ & 1.51 & 0.05 & 0.59 \\
\hline & $\mathrm{ILR}_{\mathrm{MOP}-\mathrm{a}}$ & -10.7 & -11.1 & -13.5 & 1.47 & 0.22 & 0.69 \\
\hline & $I R_{\text {MOP-p }}$ & $-10 \cdot 6$ & $-11 \cdot 3$ & -14.7 & 1.44 & 0.08 & 0.62 \\
\hline \multirow[t]{4}{*}{ Liver } & $\mathrm{ILR}_{\text {leu-p }}$ & $-6 \cdot 4$ & $-8 \cdot 8$ & $-9 \cdot 6$ & 1.77 & 0.30 & 0.62 \\
\hline & $\mathrm{ILR}_{\text {leu-h }}$ & $-7 \cdot 3$ & -9.9 & $-10 \cdot 6$ & 1.64 & 0.25 & 0.56 \\
\hline & $I^{\prime L R} R_{M O P-p}$ & $-7 \cdot 2$ & $-9 \cdot 4$ & $-9 \cdot 2$ & 1.57 & 0.47 & 0.49 \\
\hline & ILR ${ }_{\text {MOP-h }}$ & $-6 \cdot 8$ & -8.9 & -8.7 & 1.15 & 0.38 & 0.38 \\
\hline \multirow{4}{*}{ TSP } & $\mathrm{ILR}_{\text {leu-a }}$ & $-11 \cdot 3$ & -14.4 & $-16 \cdot 1$ & 1.83 & 0.16 & 0.62 \\
\hline & $\mathrm{ILR}_{\text {leu-h }}$ & -16.5 & -21.8 & -24.5 & 3.54 & 0.21 & 0.63 \\
\hline & $\mathrm{ILR}_{\mathrm{MOP}-\mathrm{a}}$ & $-16 \cdot 3$ & $-20 \cdot 7$ & -20.8 & $2 \cdot 30$ & 0.28 & 0.40 \\
\hline & $\mathrm{ILR}_{\mathrm{MOP}-\mathrm{h}}$ & -15.4 & -19.5 & $-19 \cdot 9$ & $2 \cdot 22$ & 0.27 & 0.41 \\
\hline
\end{tabular}

PDV, portal-drained viscera; ILR, irreversible loss rate.

* For details of diets and procedures, see pp. 458-460.

† ILR calculated using, as precursor pool, leucine (leu) or 4-methyl 2-oxopentanoate (MOP), from the arterial $(\mathrm{a})$, the portal $(\mathrm{p})$ or the hepatic $(\mathrm{h})$ sampling site.

day followed similar trends to leucine used for protein synthesis, but with a significant quadratic effect $(P<0 \cdot 01)$ indicating a larger increment between medium and high intakes compared with that one between low and medium intakes. Intake tended to affect, both linearly $(P=0 \cdot 10)$ and quadratically $(P=0.09)$, protein degradation, with no change or even a slight decrease between low and medium intakes and an increased protein breakdown between medium and high intakes. Protein retention was negative in the low group and increased linearly $(P<0.01)$ with intake. 
Table 6. Isotopic enrichment (atom \% excess) of plasma leucine and of 4-methyl 2-oxopentanoate (MOP) measured during $\left[1-{ }^{13} \mathrm{C}\right]$ leucine infusion in growing beef steers fed at different intake levels*

(Values are least squares means with their maximal standard errors)

\begin{tabular}{llllllll}
\hline & & & & & & \multicolumn{2}{c}{$\begin{array}{c}P \text { value } \\
\text { for treatment effect }\end{array}$} \\
\cline { 6 - 8 } Intake... & $n$ & Low & Medium & High & SEM & linear & quadratic \\
\hline $\begin{array}{l}\text { Leucine } \\
\text { arterial }\end{array}$ & $6 \dagger$ & 3.87 & 3.34 & 2.34 & 0.122 & 0.001 & 0.59 \\
$\begin{array}{l}\text { portal } \\
\text { hepatic }\end{array}$ & 5 & 3.06 & 2.50 & 1.69 & 0.114 & 0.001 & 0.94 \\
MOP & 4 & 2.83 & 2.40 & 1.64 & 0.113 & 0.002 & 0.71 \\
$\begin{array}{l}\text { arterial } \\
\text { portal }\end{array}$ & $6 \dagger$ & 2.75 & 2.38 & 1.81 & 0.057 & 0.001 & 0.90 \\
hepatic & 5 & 2.74 & 2.37 & 1.68 & 0.072 & 0.001 & 0.61 \\
\hline
\end{tabular}

* For details of diets and procedures, see pp. 458-460. †Except for medium intake where $n 5$.

\section{Splanchnic tissue metabolism}

Both portal and hepatic plasma flows increased linearly $(P<0.05)$ with increasing intake (Table 2$)$. There was net appearance of leucine across the PDV at all intakes (Table 4), although at low intake, the portal-arterial difference was not significantly different from zero $(P>0 \cdot 10$, results not shown). The net appearance increased $(P<0 \cdot 01)$ between each intake by approximately equal amounts, 6$7 \mathrm{mmol} / \mathrm{h}$. In contrast, there was only a small extraction of leucine by the liver which was unaffected $(P>0.10)$ by intake. In consequence, net appearance of leucine across the splanchnic bed increased linearly $(P<0 \cdot 01)$ with intake. The increased net entry rate into the post-splanchnic circulation was reflected by increases $(P<0 \cdot 01)$ in arterial plasma leucine concentration, which averaged 118, 138 and 167 (SEM 8.5) $\mu \mathrm{mol} / \mathrm{l}$ for low, medium and high intakes respectively.

Leucine kinetics across the TSP are presented in Table 5. Mean leucine ILR through the PDV, in absolute terms, increased with intake $(P<0.05$, based on portal vein leucine as precursor; $P=0.08$, based on arterial leucine or on venous MOP). This response was not detected $(P=0.22)$ when arterial MOP was selected as precursor. Again, when including the various precursors as repeated measurements, there was an effect $(P<0 \cdot 01)$ of the precursor selected, but the interaction was only significant $(P=0.02)$ for 'treatment $\times$ precursor pool' when comparing arterial and portal leucine. As observed for whole-body values, this indicates that the choice of the precursor pool affected the numerical estimation of ILR but did not introduce a bias when testing the treatment means. Leucine PDV ILR represented 28, 26 and 24 (SEM 3.0) \% of whole-body ILR for low, medium and high intakes respectively.

Although leucine ILR through the liver and the TSP increased numerically with intake, these were not significantly different $(P>0 \cdot 10)$. Means calculated with the various precursor pools differed $(P<0 \cdot 01)$, but there was no interaction $(P>0 \cdot 10)$ between treatments and the precursor pools used for calculations. Liver and TSP ILR represented 20, 23 and $16(\mathrm{SEM} 3 \cdot 2) \%$ and 45, 50 and 37 (SEM 4.4$) \%$ of whole-body ILR respectively, as intake increased.
IE values of leucine and MOP are presented in Table 6. Leucine and MOP IE decreased linearly $(P<0.05)$ with increasing intake. There was substantial dilution $(21-28 \%$; $P<0.001)$ of leucine enrichment across the PDV, reflecting both net absorption of unlabelled amino acid and turnover of digestive tract tissues. Much smaller leucine dilution occurred $(3-8 \% ; P<0.01)$ across the liver. In arterial plasma, MOP enrichments were lower $(P<0.001)$ than those of leucine, averaging fairly similar proportions, between 71 and $77 \%$, across intakes. The IE of arterial MOP was not changed $(P>0 \cdot 10)$, however, by transit across the PDV and it even increased $(P=0.001)$ during its passage across the liver. As a result, MOP enrichment was greater $(P<0.01)$ than leucine enrichment in the hepatic venous plasma.

\section{Discussion}

\section{Whole-body irreversible loss rate}

Whole-body ILR obtained in the present study in animals fed on the high intake, using $\left[{ }^{13} \mathrm{C}\right]$ leucine infusion $(57 \mathrm{mmol} / \mathrm{h}$ with plasma arterial MOP as the precursor pool; $45 \mathrm{mmol} / \mathrm{h}$ with plasma arterial leucine as the precursor) is similar to those obtained in studies using $\left[{ }^{14} \mathrm{C}\right] l e u-$ cine infusion (average: $49 \mathrm{mmol} / \mathrm{h}$; with blood or plasma leucine as the precursor pool) in beef cattle of similar size and intake (Lobley et al. 1985, 1987; Hammond et al. 1987; Eisemann et al. 1989b). Although the ILR technique has limitations, it does provide a relatively simple non-invasive approach to determine semi-quantitatively the effect of treatments on whole-body protein metabolism. This can be extended to tissue level using catheterized animals. One of the most important limitations of this technique is the choice of the pool that would represent best the precursor used within the cell to form the aminoacyl-tRNA. This limitation, and its impact, have been extensively discussed (e.g. Lobley et al. 1992; Schaefer \& Scott, 1993). The problem is particularly serious in studies such as the current one, where measurements of ILR at the tissue level by veno-arterial difference involve various sources of blood inflow (e.g. arterial for the PDV and portal plus 
arterial for the liver). Selection of a common value with a fixed basis is therefore inappropriate. Any plasma pool will probably underestimate the correct ILR or protein synthesis, as the enrichment of the plasma amino acid or its oxo-acid will probably be greater than that of the aminoacyl-tRNA (Airhart et al. 1974; Quinn Baumann et al. 1994). Providing these limitations are borne in mind, the technique can provide useful information on the changes induced by treatments or physiological status.

Increasing intake elevated whole-body ILR, a pattern reported in many species including cattle (Hammond et al. 1987; Lapierre et al. 1996), but as in the observations of Lobley et al. (1987), the increment was more than twice as great between medium and high intakes compared with that between low and medium intakes. Whole-body leucine oxidation, as well as fractional oxidation, also increased with intake, although for the latter, the numerical increment was smaller between medium and high intakes than between low and medium intakes. Fractional oxidation rates for steers fed on the medium and high intakes were in the range of values previously reported for cattle given maizebased diets (15-19\%; Eisemann et al. 1986, 1989b; Hammond et al. 1987; Lapierre et al. 1996). Lobley et al. (1987) reported lower absolute fractional oxidation values for steers fed on a barley straw ration, a diet with a lower leucine content. In the current experiment, a decreased fractional oxidation with a lower intake indicates that leucine was spared from oxidation to allow a greater proportion of whole-body ILR to be directed towards protein synthesis. Thus, a larger proportion of leucine turnover is recycled back to tissue metabolism. As the difference between absorption and oxidation determines accretion, any decrease in amino acid catabolism would lead to an improvement of animal performance, at a similar $\mathrm{N}$ intake. This was exactly the effect of somatotropin treatment in growing steers, where protein accretion was increased with no effect on whole-body ILR but a concomitant decrease in leucine oxidation (Eisemann et al. 1989b). This indicates, again, the importance of measuring oxidation of an amino acid when using ILR to calculate protein synthesis, as it may represent up to $20 \%$ of wholebody ILR, and this proportion might be altered by treatment. If respiratory chambers are not available, the infusion of $\left[{ }^{13} \mathrm{C}\right]$-sodium bicarbonate, conducted on a separate day to amino acid infusion, will allow the estimation of this important variable.

Decreasing intake below maintenance level slightly decreased protein synthesis while increasing protein degradation. Thus, the required net mobilization of body protein reserves was achieved by augmentation of the catabolic process rather than depression of protein synthesis. These results corroborate those observed in cattle (Lobley et al. 1987) and sheep (Harris et al. 1992), where changes in $\mathrm{N}$ retention below maintenance appeared to involve primarily modulation of proteolysis. Increasing feed intake above maintenance altered both synthesis and degradation, but with greater stimulation of the former and increased protein retention as the result. Again, these findings are comparable with previous reports in cattle (Lobley et al. 1987) and sheep (Harris et al. 1992). The apparent efficiency of protein accretion over protein synthesis between high and medium intakes averaged 0.36 , which is in the same range as estimations calculated by Lobley et al. (1987) and Hammond et al. (1987). These low values indicate that, above maintenance, the equivalent of $64 \%$ of the increment in protein synthesis is degraded which, if partly inhibited, could result in substantial increments in protein accretion. There are limits, however, to such dynamic improvements in that net gain cannot exceed net uptake.

\section{Splanchnic net fluxes}

Net portal leucine absorption increased with intake, as already observed in cattle (Hammond et al. 1987) and sheep (Pell et al. 1986). Net leucine hepatic uptake was unaffected by intake, as was the case for fasted or fed sheep (Pell et al. 1986). Even at high intake, the ratio hepatic removal : portal absorption of leucine averaged only $0 \cdot 12$, which is lower than the 0.58 reported for total $\alpha$-amino $\mathrm{N}$ (Reynolds et al. 1992). In pregnant dry cows, leucine had the smallest hepatic fractional extraction of essential amino acids, with less than $1 \%$ of the absorbed leucine being removed by the liver in basal conditions (Wray-Cahen et al. 1997). These values may reflect different metabolic requirements of rapidly growing steers compared with mature, albeit pregnant, animals. Similarly, in sheep, leucine had the smallest ratio hepatic removal : portal appearance of essential amino acids, with an average value of 0.35 (Lobley et al. 1996). Therefore, it appears that, on a net basis, leucine, as with the other branched-chain amino acids, must be mainly utilized in peripheral tissues (Pell et al. 1986).

Net portal absorption represented 1, 16 and $23 \%$ of whole-body leucine ILR, for low, medium and high intakes respectively. These values are similar to those reported for beef heifers fed at slightly above maintenance $(18 \%)$ or at a high intake (25\%; Hammond et al. 1987). This ratio might be slightly underestimated because portal absorption does not account for leucine absorbed from the intestine and used (oxidation plus accretion) by the gut before reaching the portal vein. Based on an average $27.5 \%$ of whole-body leucine oxidation occurring at PDV level (Lapierre et al. 1997), a better estimation of leucine absorbed from the diet would be $1.22,9.00$ and 16.81 (SEM 1.55 ) $\mathrm{mmol} / \mathrm{h}$. On the other hand, the whole-body leucine ILR estimated using arterial MOP as the precursor pool is also an underestimation. The relatively small contribution of leucine absorbed from the diet to the total flux also emphasizes the magnitude of protein degradation and its importance in protein turnover as whole-body ILR can be increased by as much as twice the incremental portal absorption. As much as $84 \%$ of adjusted leucine portal absorption was oxidized at the medium intake, and $69 \%$ at the high intake, indicating that leucine oxidation forms an important component of amino acid metabolism, although it represents less than $20 \%$ of whole-body ILR. At the low intake, leucine oxidation exceeded net leucine portal absorption, indicating that the animals used body proteins liberated from tissue mobilization.

\section{Splanchnic irreversible loss rate}

The contribution of splanchnic metabolism to variations observed in whole-body protein metabolism has received 
limited attention in ruminants, particularly in cattle, despite the intense metabolic activity associated with these tissues. The ILR through the PDV increased with intake, to a greater extent numerically in steers given medium $v$. high compared with low $v$. medium intakes. In calves under a cold environment $\left(-5^{\circ}\right)$, the absolute rate of protein synthesis of the gastrointestinal tract (GIT) compartments (rumen, omasum and intestine) increased non-significantly with feed intake (Scott et al. 1993). Similarly, in sheep there was a nonsignificant trend for an increased fractional synthesis rate for most components of the GIT when intake increased from 1.2 to 2 times maintenance (Lobley et al. 1994). In other studies conducted in sheep, increasing feed intake increased protein synthesis in the small intestine (Neutze et al. 1997) and across the PDV (McRae et al. 1997). These findings indicate that increasing intake increases the absolute rate of protein synthesis by the GIT. In the current study, however, the relative contribution of the PDV to whole-body ILR, numerically decreased with increasing intake, from 28 to 26 to $24 \%$. In sheep, increasing intake did not markedly affect the PDV contribution to whole-body leucine flux (MacRae et al. 1997), with an estimated average value of about $38 \%$ when considering only sequestration of arterial leucine. In contrast, in another sheep study, the proportional contribution of the small intestine to whole-body protein synthesis tended to increase from $13 \%$ at a low intake to $21 \%$ at a high intake (Neutze et al. 1997). Although values obtained in sheep in these two last experiments, which both used the veno-arterial technique, seem to indicate a higher contribution of the GIT to whole-body protein metabolism in sheep compared with cattle, another study conducted in sheep with the same technique yielded a PDV contribution to whole-body protein metabolism of approximately $24 \%$ (Lobley et al. 1996), closer to that observed here for cattle.

In the present study, the liver did not show a significant increment in ILR with increasing intake. In sheep, increasing intake did not affect liver fractional synthesis rate, but hepatic weight increased with intake (Lobley et al. 1994), which would have resulted in a higher absolute synthesis rate in animals fed on the higher intake. Intake was reported to differentially affect protein synthesis by the ovine liver: constitutive protein was unaffected but export protein increased (Connell et al. 1997). There is probably an upper limit to the plasma protein synthesis, as increased supply of amino acids does not increase the rate further (Lobley et al. 1998). These reasons might account for the lack of response to intake of liver ILR, especially above maintenance.

The important contribution of the splanchnic tissue to whole-body protein metabolism is in agreement with a similar contribution of TSP to whole-body $\mathrm{O}_{2}$ consumption (Reynolds et al. 1992) and reinforces the metabolic importance of the TSP. Although the proportional contributions of the TSP to whole-body ILR were not affected by intake, on an incremental basis, the TSP contributed between 71 and $73 \%$ of the change in whole-body leucine ILR when intake was raised from 0.6 to $1 \times$ maintenance, but less than $13 \%$ when intake increased above maintenance, depending on which precursor pool was chosen. This reduced contribution at the higher intake indicated that the metabolic activity of peripheral tissues increased as the animal moved into positive protein balance.
Values reported previously for the contribution of the splanchnic tissue to whole-body ILR or whole-body protein synthesis in cattle were estimated from fractional synthesis rates calculated based on incorporation of a radiolabelled amino acid into tissue proteins after a continuous infusion. This technique requires biopsies or slaughter of the animals and the data were calculated using either a peripheral vascular or homogenate (intracellular) pool. Previous studies with cattle, based on use of $\left[{ }^{14} \mathrm{C}\right]$ leucine have indicated that the contributions of GIT and liver protein synthesis to whole-body protein synthesis in growing cattle averaged 32.4 and $4.0 \%$ (Lobley et al. 1980), 22.4 and $4.5 \%$ (Early et al. 1990) respectively. Values obtained in the present study based, for comparative purposes, on arterial $\left[{ }^{13} \mathrm{C}\right]$ leucine as the precursor pool, are similar for the GIT to these reported values, while the estimations of liver contribution are substantially higher. The veno-arterial difference technique estimates the synthesis of both constitutive and export proteins, while the incorporation techniques account for constitutive proteins plus the fraction of export proteins still present in the cells at the time of sampling. As synthesis of export proteins can represent between 17 and $43 \%$ of hepatic protein synthesis in ruminants (e.g. Connell et al. 1997), this needs to be accounted for either by use of a short-term large dose technique (Lobley et al. 1994) or measurement of isotopic incorporation into the plasma protein pool (Connell et al. 1997). Even when this additional accounting is applied, values obtained with the veno-arterial difference technique are still higher, by approximately $20 \%$. As a result of this higher estimated hepatic amino acid flux with the veno-arterial technique, the liver contribution relative to the GIT in our study is higher than that reported using the incorporation technique. The liver contribution to whole-body protein metabolism was estimated to be only one-third of the GIT contribution in sheep (Davis et al. 1981; Attaix et al. 1988; Lobley et al. 1994), and even less in the cattle studies (Lobley et al. 1980; Early et al. 1990). In our present study, the proportional contribution of the liver to whole-body leucine flux was $75 \%$ that of the PDV. Lobley et al. (1996), using the venoarterial difference, reported that liver contribution to wholebody leucine flux was approximately half of the PDV contribution.

In many studies, the IE of the arterial MOP, which is formed intracellularly from deamination of leucine, is used and assumed to be closer to the IE of the leucine bound to tRNA than the IE of arterial leucine. In the current study, at whole-body level, the use of MOP enrichment yielded higher ILR values than data based on arterial leucine, which yielded probably the lowest underestimation of whole-body ILR. There was, however, no interaction between treatment and precursor pool, indicating that no bias was introduced by the selection of one precursor pool or another. In human subjects, reciprocal pool analyses based on infusions of $\left[1-{ }^{13} \mathrm{C}\right] \mathrm{MOP}$ have shown plasma oxo-acid enrichment to be a good reflection of intracellular leucine enrichment in muscle (Chinkes et al. 1996). Similarly, in pigs, plasma MOP predicted leucyl-tRNA with high accuracy in skeletal muscle but the relationship was not as close for the liver (Quinn Baumann et al. 1994). The stability of MOP enrichment across both the PDV and the liver supports 
earlier suggestions that MOP isotopic activities do not reflect well leucine transfers across the splanchnic tissues. Thus, plasma MOP IE is dominated, probably, by muscle metabolism and the oxo-acid enrichment does not reflect leucine intracellular metabolism within visceral tissues.

These data confirm the major contribution that the splanchnic tissues make to whole-body protein metabolism, similar to the well-defined situation for energy expenditure. The use of a veno-arterial approach has allowed, however, the proportional contribution to be examined under different dietary regimens. Previous studies, based on slaughter and tissues analyses, suffered from the difficulties in resolving inter-animal from inter-treatment effects, but the repeated measurements on the same animal have reduced some of these problems. In response to higher intakes, there is clearly a decrease in the proportional contribution of the splanchnic tissues to whole-body protein metabolism, although both are increased in absolute amounts. The current data do not permit discrimination of specific syntheses, e.g. constitutive $v$. export protein or secreted proteins, and these may change in response to particular nutritional or physiological demands (fibrous feed, infection, etc.). Nonetheless, the priority of the animal to maintain high rates of metabolism of the functional organs comprising the digestive tract and the liver, even at reduced intake, is counterbalanced by a reduced proportional (but not absolute) role when intake is sufficient to support peripheral tissue metabolism.

\section{Acknowledgements}

The authors thank A. G. Calder, D. Bertrand, M. Léonard, and A. Roy for their skilled assistance for blood sampling and analyses, as well as S. Methot for statistical analyses. This work was partly supported by a grant from the Natural Sciences and Engineering Research Council of Canada and, as part of the core budget of the Rowett Research Institute, from the SOAEFD; Lennoxville Research Centre contribution number: 601 .

\section{References}

Airhart J, Vidrich A \& Khairallah EA (1974) Compartmentation of free amino acids for protein synthesis in rat liver. Biochemical Journal 140, 539-548.

Attaix D, Aurousseau E, Manghebati A \& Arnal M (1988) Contribution of liver, skin and skeletal muscle to whole-body protein synthesis in the young lamb. British Journal of Nutrition 60, 77-84.

Bequette BJ, Metcalf JA, Wray-Cahen D, Backwell FRC, Sutton JD, Lomax MA, MacRae JA \& Lobley GE (1996) Leucine and protein metabolism in the lactating dairy cow mammary gland: responses to supplemental dietary crude protein intake. Journal of Dairy Research 63, 209-222.

Boisclair YR, Bell AW, Dunshea FR, Harkins M \& Bauman DE (1993) Evaluation of the arteriovenous difference technique to simultaneously estimate protein synthesis and degradation in the hindlimb of fed and chronically underfed steers. Journal of Nutrition 123, 1076-1088.

Calder AG \& Smith A (1988) Stable isotope ratio analysis of leucine and ketoisocaproic acid in blood plasma by gas chromatography/mass spectrometry. Use of tertiary butyldimethylsilyl derivatives. Rapid Communications in Mass Spectrometry 2, $14-16$.

Canadian Council on Animal Care (1993) Guide to the Care and Use of Experimental Animals, vol. 1. [ED Offert, BM Cross and AA McWilliam, editors]. Ottawa, Ont.: CCAC.

Chevalier R, Pelletier G \& Gagnon M (1984) Sampling technique for collection of expired $\mathrm{CO}_{2}$ in studies using naturally labelled

${ }^{13} \mathrm{C}$ in calves. Canadian Journal of Animal Science 64, 495-498.

Chinkes D, Klein S, Zhang X-J \& Wolfe R (1996) Infusion of labeled KIC is more accurate than labeled leucine to determine human muscle protein synthesis. American Journal of Physiology 270, E67-E71.

Connell A, Calder AG, Anderson SE \& Lobley GE (1997) Hepatic protein synthesis in the sheep: effect of intake as monitored by use of stable-isotope-labelled glycine, leucine and phenylalanine. British Journal of Nutrition 77, 255-271.

Davis SR, Barry TN \& Hughson GA (1981) Protein synthesis in tissues of growing lambs. British Journal of Nutrition 46, 409419.

Early RJ, McBride BW \& Ball RO (1990) Growth and metabolism in somatotropin-treated steers: III. Protein synthesis and tissue energy expenditures. Journal of Animal Science 68, 4153-4166.

Eisemann JH, Hammond AC, Bauman DE, Reynolds PJ, McCutcheon SN, Tyrrell HF \& Haaland GL (1986) Effect of bovine growth hormone administration on metabolism of growing Hereford heifers: protein and lipid metabolism and plasma concentrations of metabolites and hormones. Journal of Nutrition 116, 2504-2515.

Eisemann JH, Hammond AC \& Rumsey TS (1989a) Tissue protein synthesis and nucleic acid concentrations in steers treated with somatotropin. British Journal of Nutrition 62, 657-671.

Eisemann JH, Hammond AC, Rumsey TS \& Bauman DE (1989b) Nitrogen and protein metabolism and metabolites in plasma and urine of beef steers treated with somatotropin. Journal of Animal Science 67, 105-115.

Gill JL (1978) Design and Analysis of Experiments in Animal and Medical Science. Ames, IA: Iowa State University Press.

Hammond AC, Huntington GB, Reynolds PJ, Tyrrell HF \& Eisemann JH (1987) Absorption, plasma flux and oxidation of L-leucine in heifers at two levels of intake. Journal of Animal Science 64, 420-425.

Harris PM, Skene PA, Buchan V, Milne E, Calder AG, Anderson SE, Connell A \& Lobley GE (1992) Effect of food intake on hind-limb and whole-body protein metabolism in young growing sheep: chronic studies based on arterio-venous techniques. British Journal of Nutrition 68, 389-407.

Huntington GB, Reynolds CK \& Stroud B (1989) Techniques for measuring blood flow in splanchnic tissues of cattle. Journal of Dairy Science 72, 1583-1595.

Katz ML \& Bergman EN (1969) Simultaneous measurements of hepatic and portal venous blood flow in the sheep and dog. American Journal of Physiology 216, 946-952.

Lapierre H, Blouin JP, Lobley GE, Reynolds CK, Dubreuil P \& Bernier JF (1997) Effect of protein degradability on protein splanchnic metabolism in dairy cows. Proceedings of the Nutrition Society 56, 162A.

Lapierre H, Pelletier G, Ouellet DR, Lobley GE \& Bernier JF (1996) Measuring leucine flux and protein metabolism with carbon-13 isotope in growing cattle. Canadian Journal of Animal Science 76, 259-262.

Lobley GE, Bremner DM, Nieto R, Obitsu T, Hotston Moore A \& Brown DS (1998) Transfers of $\mathrm{N}$ metabolites across the ovine liver in response to short-term infusions of an amino acid mixture into the mesenteric vein. British Journal of Nutrition 80, 371-379.

Lobley GE, Connell A \& Buchan V (1987) Effect of food intake on 
protein and energy metabolism in finishing beef steers. British Journal of Nutrition 57, 457-465.

Lobley GE, Connell A, Milne E, Newman AM \& Ewing TA (1994) Protein synthesis in splanchnic tissues of sheep offered two levels of intake. British Journal of Nutrition 71, 3-12.

Lobley GE, Connell A, Mollison GS, Brewer A, Harris CI \& Buchan V (1985) The effects of a combined implant of trenbolone acetate and oestradiol-17 $\beta$ on protein and energy metabolism in growing beef steers. British Journal of Nutrition 54, 681-694.

Lobley GE, Connell A, Revell DK, Bequette BJ, Brown DA \& Calder AG (1996) Splanchnic-bed transfers of amino acids in sheep blood and plasma, as monitored through use of a multiple $\mathrm{U}-{ }^{13} \mathrm{C}$-labelled amino acid mixture. British Journal of Nutrition 75, 217-235.

Lobley GE, Harris PM, Skene PA, Brown D, Milne E, Calder AG, Anderson SE, Garlick PE, Nevison I \& Connell A (1992) Responses in tissue protein synthesis to sub- and supra-maintenance intake in young growing sheep: comparison of largedose and continuous-infusion techniques. British Journal of Nutrition 68, 373-388.

Lobley GE, Milne V, Lovie JM, Reeds PJ \& Pennie K (1980) Whole body and tissue protein synthesis in cattle. British Journal of Nutrition 43, 491-502.

MacRae JC, Bruce LA, Brown DS \& Calder AG (1997) Amino acid use by the intestinal tract of sheep given lucerne forage. American Journal of Physiology 273, G1200-G1207.

National Research Council (1984) Nutrient Requirements of Beef Cattle, 6th ed. Washington, DC: National Academy Press.

Neutze SA, Gooden JM \& Oddy VH (1997) Measurements of protein turnover in the small intestine of lambs. 2. Effects of feed intake. Journal of Agricultural Science 128, 233-246.
Pell JM, Caldarone EM \& Bergman EG (1986) Leucine and $\alpha$ ketoisocaproate metabolism and interconversions in fed and fasted sheep. Metabolism 35, 1005-1016.

Quinn Baumann P, Stirewalt WS, O'Rourke BD, Howard D \& Nair S (1994) Precursor pools of protein synthesis: a stable isotope study in swine model. American Journal of Physiology 267, E203-E209.

Read WW, Read MJ, Griggs RC \& Halliday D (1984) Preparation of $\mathrm{CO}_{2}$ from blood and protein-bound amino acid carboxyl groups for quantification of ${ }^{13} \mathrm{C}$-isotope enrichments. Biomedical Mass Spectrometry 15, 467-472.

Reynolds CK, Lapierre H, Tyrrell HF, Elsasser TH, Staples RC, Gaudreau P \& Brazeau P (1992) Effects of growth hormonereleasing factor and feed intake on energy metabolism in growing beef steers: net nutrient metabolism by portal-drained viscera and liver. Journal of Animal Science 70, 752-763.

Schaefer AL \& Scott SL (1993) Amino acid flooding doses for measuring rates of protein synthesis, review article. Amino Acids 4, 5-19.

Scott S, Christopherson RJ, Thompson JR \& Baracos VE (1993) The effect of a cold environment on protein and energy metabolism in calves. British Journal of Nutrition 69, 127139.

Wolfe RR (1984) Tracers in Metabolic Research. Radioisotope and Stable Isotope/Mass Spectrometry Methods. New York, NY: Alan R. Liss, Inc.

Wray-Cahen D, Metcalf JA, Backwell FRC, Bequette BJ, Brown DS, Sutton JD \& Lobley GE (1997) Hepatic response to increased exogenous supply of plasma amino acids by infusion into the mesenteric vein of Holstein-Friesian cows in late gestation. British Journal of Nutrition 78, 913-930. 